DOI https://doi.org/10.18551/rjoas.2017-07.20

\title{
DECIDING THE EMPLOYEE ENGAGEMENT DIMENSION IN INDONESIA AND GLOBAL: A CONCEPTUAL MODEL
}

\author{
Adi Agung Nugroho, Lecturer \\ Faculty of Economics and Business, University of Brawijaya, Indonesia \\ E-mail: agungnugrohoadi@yahoo.co.id
}

Fithriana Noora, Lecturer

Faculty of Political and Social Sciences, University of Tribhuwanatunggadewi, Indonesia E-mail: noorafithriana@gmail.com

\begin{abstract}
Human resource concern is important to do to boost organizational performance significantly. Employee engagement as the tools of human resource management is important to improved organizational performance through human resource perspective. Indonesia as the largest country in the world (the largest similar with Europe United region) is attractive to investigate how the employee engagement was implemented. Divided into many ethnics with almost 200 ethnics, largest population 4rd in the world, Indonesia is special case that needed to be investigated. Remembering a few research described whole context of employee engagement in Indonesia. This study revealed employee engagement description comprehensively. This study investigated the employee engagement in Indonesia context through collecting employee engagement research in Indonesia then comparing and analyzes it with global context of employee engagement. The employee engagement external dimension plays important role than individual dimension. Global context of employee engagement has more concern on individual, job, organization, and leadership dimension equally. Harmonizing in the organization, people value similarity, and the congruity between organization vision and mission and operational field is important to boost engagement in Indonesia context.
\end{abstract}

\section{KEY WORDS}

Employee engagement, Indonesia context, global context.

Human resource management which is lead to employee engagement has been developed in last decade. The human resource management which is lead to employee engagement was shown through how to see employee not as a victim but how the organization provide their vision and integrity, accountability and meaning, problem solving in their organization (Millar, 2012). Thus, this view (employee engagement is should be create by companies) is concluded from the paradigm that employee as the object not victim. In other side, employee engagement in the past concern (employee focus) about how the employee comprehend to their work roles, feel satisfied (Kahn, 1992 in (Taneja, Sewell, \& Odom, 2015 )) and related with organizational performance outcomes, employee retention, productivity and profitability (Cataldo, 2011 in (Taneja, Sewell, \& Odom, 2015 )). Moreover, employee engagement in previous research mention about how the employee has willingness to achieve company goals, objective, and long-term sustainable competitive advantage (Little, 2006 in (Taneja, Sewell, \& Odom, 2015 )) and has positive attitude or similar value or added value in their organization (Ariani, 2013 in (Taneja, Sewell, \& Odom, 2015 )). In summary, employee engagement dimension in global context could be supported as communication, training and development, mobility \& development, talent management, reward \& recognition, leadership, organizational involvement, focus on customers, employee empowerment, work life balance, reward employees (Taneja, Sewell, \& Odom, 2015 ). The last major view of past perspective that influenced engagement perspective is employee engagement as the employee positive attitude such as, vigor, dedication, and absorption (Schaufeli, Salanova, Gonzalez-Roma, \& Bakker, 2002) in their organization. 
Indonesia as the one of country with highest economics growth in South-East Asia (Asian Development Outlook , 2016) and highest $4^{\text {nd }}$ population (Worldometers, 2015) is very interesting to be investigated. Indonesia population reach 255 million which average population is 28.6 years old or almost 125 million (in productivity phase) (Indonesia Investments , 2016), also, Indonesia manufactured and construction sector plays important role in Indonesia economic growth (Tradingeconomics, 2015). The combination both manufactured and construction sector provide almost 730.000 billion every year (Tradingeconomics, 2015). Thus, how the Indonesia achieved highest economic growth in Asia after China (in first quartile in 2016) is not getting lose from how the company manage their human resource. It is proven from the Indonesia economic growth suitable with as much as productivity population phase in Indonesia. The human resource management is shown through population growth since 2010-2016 which is increase significantly (Worldometers, 2015). And, the human resource management always leads to employee engagement. Unfortunately, even employee engagement is very important in organization performance and improve economic growth (Farndale, Kelliher, \& Hope-Hailey, 2014) (Tiwari \& Lenka, 2016), the comprehension of employee engagement in Indonesia only available in a few discussion. Even, Indonesia has complexity varies of population in the world also the largest $4^{\text {nd }}$ population in the world. So, it is necessary to investigate the dimension of employee engagement in Indonesia context.

This study will investigate employee engagement in Indonesia. Investigating the other dimension of employee engagement dimension in Local context will added in this study. Even use many literatures which is related with employee engagement, this study will also considering the first deduction or similar with hypotheses every literature abroad related with employee engagement and employee engagement research result every researcher in the Indonesia. Thus, this study will find out the whole picture about employee engagement in Indonesia combining with global context.

Employee Engagement Indonesia Context. Employee engagement as the new context of job satisfaction is related with job performance and job satisfaction, and competitive advantage (Widjaja \& Devie, 2014). Employee engagement is positive feeling that employee have related with their organization and their organization value (Widjaja \& Devie, 2014). Moreover, this study elaborates employee engagement as the mediation variable between job satisfaction, competitive advantage, and organizational performance (Widjaja \& Devie, 2014). Figure 1 will show the relationship between those variables.

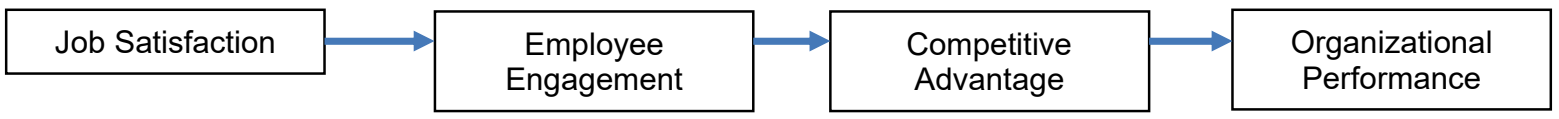

Figure 1 - The relationship between Job Satisfaction, Employee Engagement, Competitive advantage, and Organizational Performance

The research participants are 179 employees (49.72\% is male and $50.28 \%$ is female) from 20 companies (employee with 3-5 year experience is $50.28 \%$ and $5-10$ year experiences is $43.02 \%$ ) in Surabaya city. The analysis tools use Partial Least Square (PLS). And, the result from this research is job satisfaction has positive relationship and significant to employee engagement, employee engagement has positive relationship and significant to competitive advantage, competitive advantage has positive relationship and significant to financial performance (Widjaja \& Devie, 2014).

Employee engagement dimension in this research was four kinds dimension from Gallup which is contained (1) what do I get-dimension, (2) What do I give-dimension, (3) Do I Belong-dimension, (4) how can we grow-dimension (Widjaja \& Devie, 2014). What do I getdimension is contained expectation and company facilities, What do I Give-dimension is contained workplace, work acknowledgment, supervisor attention, colleagues support, Do I belong-dimension is contained involvement, job importance, colleagues commitment, trusted colleagues, How can we grow-dimension is contained progress report, growth (personal achievement) (Widjaja \& Devie, 2014). 
Employee engagement is positive condition that was expected by the company or organization considering employee attitude and behavior that involved themselves with consciousness (physical, emotion, feeling, vigor) in purpose to booster the performance to achieve company objectives and goal (Wijaya, 2015). Thus, in purpose to gain employee engagement, the company can be built from good internal communication inside the organization and organization culture. The internal communication involved (1) event, (2) structure (formal and informal), (3) flow (downward and upward), (4) Content (organizational and personalized), (5) Climate (openness, participation, equality and supportiveness). Thus, next step is organization culture involves (1) touching human feel or emotion, (2) 8M culture, (3) "Good people" motto, (4) Value System, (5) reward and punishment (Wijaya, 2015). The study use qualitative method which is involved 9.046 employees in Unknown companies (PT. X).

Employee engagement is related with organization environment, demographic characteristic, social characteristic, and organization performance. Employee engagement important to counter the employee turnover in the organization especially in Banking sector (Putri, Baga, \& Sunarti, 2015 ). Even compensation play important role to booster employee commitment but it is not always effective to keep employee to This study defined the variable (1) Employee engagement can be defined as employee feeling or perception about their workplace, compensation, and workplace equally, (a) achievement (job challenges, growth opportunities chance, work ability, job importance, appreciation, and work rightfully proud), (b) Camaraderie ( colleagues relation, team work, team work with other division, and work team entire the organization) (c) Leadership (instruction, decision making, encouragement, communication, guidance, discipline, supervisory, warning) (2) demographic characteristic (gender, age, education, job, job experience, income, and marital status) (3) Social characteristic (economic condition-job status, income, and life style, interaction-reward, politics-power and leadership, social supporting) (4) Organization performance (outcome quantity, work process, work quality, accuracy, absenteeism, team work ability (Putri, Baga, \& Sunarti, 2015 ). The research population is 480 permanent employees, non-permanent employees, and outsourcing employees which is has sample as many as 83 employees. The research revealed employee engagement has positive relationship and significant to employee performance, Social environment has positive relationship and significant to employee performance, job status has negative relationship and not significant to employee performance, gender has negative relationship and not significant to employee performance (Putri, Baga, \& Sunarti, 2015 ).

Employee engagement is constructed and created depend from how the organization provide employee compensation, status, and growth opportunities (Harry N, 2014). Employee engagement as the feeling energize (vigor), dedicated into their work (dedication), commitment and find difficult to detach from their work (Cook, 2008; May, Gilson, \& Harter, 2004; Bakker, Schaufeli, Leiter, \& Taris, 2008 in Harry N (2014)) is created from how the organization their employees compensation (financial, services, and benefits return given to the employees as the consequences from their work relationship (Milkovich and Newman, 2002 in Harry, 2014)), status is employee ability recognition from their employer related with acceptance, amazed, recognition certificate, recognition article, and certain program such as employee of the month which is divided into two kinds (informal such as, employee of the month and formal such as, new position, stock ownership etc) (Milkovich \& Newman, 2002 in Harry (2014)). The Harry (2014) research involves 248 employees in Sanata Dharma University. The result is compensation, recognition, and equally opportunities has positive relationship and significant to employee engagement (Harry N, 2014).

The total returns impact to employee engagement significantly. Starts from many lecturers resign from ITB University, this research want to investigate the relationship between total returns and employee engagement (Wuladari \& Gustomo, 2011). Employee engagement as employee behavior concept that explore the effort to fully involved in their organization based on their emotional feeling with the organization to fulfilled organization purposed (Wuladari \& Gustomo, 2011). To gain entire picture of employee engagement dimension, Investigating employee engagement with compensation, employee engagement 
with recognition, employee development opportunities with employee engagement, and age and work experiences with total returns (compensation, recognition, and career development opportunities) is necessary (Wuladari \& Gustomo, 2011). How the conceptual theory develops can be seen in figure 2 .



Figure 2 - The relationship between Total return and employee engagement (Wuladari \& Gustomo, 2011)

The research participants are the lecturers from 12 faculties in Institute of Technology Bandung (ITB) (Wuladari \& Gustomo, 2011). The result of study shown (1) compensation is not influenced significantly to employee engagement, (2) recognition is influenced and positive significant to employee engagement, (3) Career Development opportunities is not influenced to employee engagement (4) that age and tenure as moderation variable booster the compensation (financial) to improve employee engagement as significantly and positive (Wuladari \& Gustomo, 2011).

Employee engagement has relationship with compensation and performance appraisal. Employee engagement can be defined as say (speak positively about the organization), stay (has willingness to stay in organization for a long time), strive (high effort, dedicated his live for his job) and compensation is financial feedback from company to their employee such as incentive, allowance, workplace environment, promotion opportunities, and job challenge, performance appraisal can be categorized as vision and mission company harmonizing, precisely, openness (Dewi, 2012). This research population conducted from 394 participants which is randomly chosen and the sample is 150 participants (with $10 \%$ sample error) (Dewi, 2012). The study revealed that both compensation and performance appraisal has positive impact and significant to employee engagement (Dewi, 2012).

Employee internal factors have influenced productivity than employee external factor. Start from phenomenon that organization provide psychology facilities manipulation but they cannot improve employee productivity (Sri Widodo \& Sami'an, 2013). So, the organization decide to get manipulate employee behavior than external manipulation. Employee engagement in this research categorized as positive motivational that involved vigor, dedication, and absorption, thus, productivity behavior can be defined as effective and efficient behavior which is effective behavior has meaning employee behavior that oriented to organization purpose (dimension of this behavior is the goal oriented, coordinating each other, accuracy, problem solving) and efficient behavior has meaning employee behavior that aware with limitation of resource to achieve organization goal (Sri Widodo \& Sami'an, 2013). Even, the study result is employee engagement does not have correlation with employee positive attitude but investigation the dimension of employee engagement expect on the contrary through many literature review in theory (Sri Widodo \& Sami'an, 2013).

Employee engagement influences to Employee performance. How the employee engagement influence employee performance starts from the paradigm that employee engagement has constructed from (1) equity (how the organization maintain their (a) workplace condition (b) compensation (c) equally feel), (2) achievement, (3) Camaraderie, (4) Leadership (how the organization provide facilities about a) balancing between organization vision and mission and operational level b) Promoting and teamwork support c) Support the employee to develop d) Support and recognition appropriately) (Ramadhan \& Sembiring, 2014). And, the employee performance related with work quantity, work quality, time accuracy, presence, ability to do teamwork. Between those variable and the dimension related each other through many research. This research participants is 74 HCC Telkom 
employees (Ramadhan \& Sembiring, 2014). Using Path Analysis to analyze the data, Result of study revealed that employee engagement has positive relationship and significant to employee performance (Ramadhan \& Sembiring, 2014).

The Employee Engagement Dimensional Global Context. Customer engagement was built from how the frontline employees role (Cambra-Fierro, Melero-Polo, \& VazquezCarrasco, 2014). Taken from the research, customer engagement can be defined as customer connection, participation, involvement or absorption and frontline employees that represent the engagement defined as "an emotional state based on their own experiences in the workplace. This attitude based on both objective and emotional issues such as salary, training received, work conditions, the socio-cultural profile of the employee, feelings towards the company or compatibility with company values, and ultimately determines whether employees are satisfied or unsatisfied" (Cambra-Fierro, Melero-Polo, \& Vazquez-Carrasco, 2014). Thus, even the Cambra-Fierro et all (2014) did not mention about the employee engagement clearly. But, employee satisfaction always lead to employee engagement (Taneja, Sewell, \& Odom, 2015 ) (Ugwu, Onyishi, \& Rodriguez-Sanchez, 2014 ) (Vance, 2006).

Employee engagement related with leadership, work life balance, organizational performance, communication (Bedarkar \& Pandita, 2014). Through many literature review, Bedarkar \& Pandita (2014) research revealed that employee engagement driver divided as employee welfare, empowerment, employee growth and interpersonal relationships, Connect, Career, Clarity, Convey, Congratulate Contribute, Control, Collaborate, Credibility \& Confidence, contributions, connections, growth and advancement, employee involvement and commitment, leadership, relationships at work, total reward, recognition, work life balance and work itself, say, stay, strive, jobs satisfaction, feeling valued and involvement, equal opportunity, health and safety, length of services, communication and co-operation, three predictors of employee engagement (rational-employee understand the role, emotionalemployee passion at workplace, motivational-employee discretionary effort to perform their role), career opportunities, brand alignment, recognition, people/hr practices, organization reputation, managing performance, pay, valuing people (Bedarkar \& Pandita, 2014). Finally, the all driver categorized as the dimension such as, organizational performance, communication, work life balance, and leadership (Bedarkar \& Pandita, 2014).

Employee engagement as the drivers of organizational performance high level constructed from the many dimensions. The dimensions of employee engagement (1) work environment (2) HRM Practices (3) employee supervisor relationship (4) job satisfaction (5) organizational culture (Kaliannan \& Narh Adjovu, 2015). The results revealed that the fifth dimension related with employee engagement.

Employee engagement as the sustainability tools created from appraisal justice, trust (Sivadahasan Nair \& Salleh, 2015). Employee engagement defined as how psychological experiences of work shape the process of people presenting and absenting themselves during task performances, performance appraisal defined as the process fairness start from regarding the methods, mechanism, and process which is acceptable between raters and ratees, trust defined as popular key to replace the organizational hierarchical control (Sivadahasan Nair \& Salleh, 2015). In order to find out the relationship between them, employee engagement dimension should be revealed first. The employee engagement dimension covered as role overload, production demands, formal procedures, social support, autonomy, performance appraisal justice, autonomy feedback, and support, turnover intention, Organizational Citizenship Behavior, commitment, job attitudes, satisfaction (Sivadahasan Nair \& Salleh, 2015). Thus, performance appraisal justice dimension as subjectivity, relationship quality, voice opportunity, uncertainty, importance, employee perception, participation, supervisor attitudes, knowledge (Sivadahasan Nair \& Salleh, 2015). Moreover, trust dimension as careerist orientation, team identification and team conflict, high servant leadership, organizational justice and practice, OCB, procedural justice, interactional justice (Sivadahasan Nair \& Salleh, 2015).

Internal communication plays important role to boost employee engagement. Internal communication categorized as two main roles: sharing of information and deliberately sense 
of communication entire the organization (Karanges, Johnston, Beatson, \& Lings, 2015). Meanwhile, employee engagement categorized as "positive, fulfilling, work-related state of mind, the benefits of employee engagement include increased productivity, decreased attrition, improvement of an organization's image and reputation, and increased financial returns" (Schaufeli et al (2002) in (Karanges, Johnston, Beatson, \& Lings, 2015)).

Employee engagement has relationship with boredom, organizational performance, and employee protection. The construction of safety that used is (1) feeling safe (incident prevention, trust and fairness along with other, realities) (2) boredom (lack of work perform, challenges, withdrawal behavior), (3) employee engagement (enthusiastic, involved, absorbed) (Whiteoak \& Mohamed, 2015), Using mix method to analyze the relationship between employee safety (Whiteoak \& Mohamed, 2015).

The reconstruction of employee engagement needed to make sure that employee engagement contained from many varies factors. Thus, in purpose to validity the employee engagement itself identification which factors influenced to employee engagement is necessary. The factors could be found in many literatures and the factors such as job satisfaction, affective organizational commitment, job involvement, vigor, dedication, absorption, focal performance, contextual performance, contribute to one's work role, social support (performance feedback, autonomy, learning opportunities, task variety), employee basic needs (autonomy, relatedness, competence), work demands (time, task difficulty), high job performance, high role performance, organizational citizenship behaviors, personal initiative, higher likelihood of promotion, absenteeism, tardiness, lower turnover and retention, les complaints, workaholism, innovative (Mackay, Allen, \& Landis, 2016).

National economic growth has been influenced by organizational performance and organizational performance depends on job satisfaction, employee engagement and work-life balance. Job satisfaction can be defined as the psychological expression resulting from employee appraisal considering employee job experiences, positive and negative feeling outcome toward the job, work-life balance defined as concern on relationships, connections between work and family which is described as work, family, personal roles, frone and his colleagues, and employee engagement categorized as "psychological state that is characterized by vigor, absorption, and dedication in one's work and its important to organizational performance (E, McNamara, Pitt-Catsouphes, \& Valcour, 2015).

The safety climate, employee engagement, and job satisfaction have correlation each other. Safety environment creates employee perceived risk, good safety which is related to the intent to remain with organization (Huang, et al., 2015). Intent to stay in the organization always to work engagement and intent to stay at organization also has first antecedents, thus, the antecedents is employee feel satisfied with their jobs then they engaged to the organization and the consequences from the relationship outcomes is employee turnover (Huang, et al., 2015). The work engagement is "motivational state whereby employees invest their physical, emotional, and cognitive resource into the work role and job performance" and employee perception about safety climate (safety training, open communication, frequent safety inspections, good housekeeping, environmental control, a stable workforce, promotion) (Huang, et al., 2015).

Employee engagement as the bridge to connect between job meaningful and organizational commitment. Job Meaningful can be defined as understanding of their selves and workplace, reciprocity or exchange, social functions, a source of status or class, and personal meaning which is divided into (1) the degree of job importance (2) entitlement norms that should developed (3) economic orientation through high perform at their job (4) colleagues relationship (5) fun expression, interest expression at workplace (6) high contribution (Jung \& Yoon, 2015). Thus, job meaningful has related with employee engagement and the employee engagement itself defined as " be a positive, fulfilling, workrelated state of mind that characterized as vigor, dedication, and absorption" (Jung \& Yoon, 2015). Then, employee engagement has relationship with organization commitment which can be defined as "the belief in and acceptance of organizational goals and values and the willingness to exert considerable effort on behalf of the organization" (Jung \& Yoon, 2015). 
Employee engagement defined as work vigorously, feeling dedicated and mentally absorbed in their work, also, have mindsets about organizational culture, managerial actions, self-development, enthusiasm for development, construal of effort, focus of attention, perspective on setbacks, interpersonal interactions (Keating \& Heslin, 2015). The whole assumptions that relate with the other factors came from how the positive feeling and behavior always appear when the employee or person will enjoyable at workplace for example, helpful characteristics rather than a judgmental manner came up from feeling happy (positive), Then, it is a evidence for engagement which is one of the engagement trait is feeling positive.

Engagement through individual view contained two dimension first is core selfevaluation and second is psychological climate (Lee \& Ok, 2015). Employee engagement defined as (1) the degree of physical, cognitive, and emotional involvement in workplace, good interactions, (2) energy, involvement, efficacy (similar with vigor, dedication and absorption) and willingness to invest effort and endurance of difficulties (Lee \& Ok, 2015). Thus, employee engagement can't be happened with two dimension there are core selfevaluation (CSE) which has meaning that "subconsciously appraise themselves, other people, and the world or reality" and "those perceptions shared among members of organization about organizational environment including policies, procedures, and practices" (Lee \& Ok, 2015). Core self-evaluation has four traits: self-esteem, self-efficacy, selfacceptance, self-liking, self-respect, locus of control, and emotional stability and Psychological climate has traits: (1) role stress and lack of harmony (2) job challenge and autonomy (3) leadership facilitation and support (4) work group cooperation, friendliness, and warmth (Lee \& Ok, 2015).

Work engagement defined as causes for organizational performance, customer loyalty, low turnover, low absenteeism, expression through themselves as physically, cognitively, and emotionally, enthusiasm, focus, and energized, persistence and adaptability, vigor dedication and absorption and work engagement is influenced four other indicator outside the employees (Kwon, Farndale, \& Park, 2016). Four indicators that influence to work engagement is intention, power distance, participative organizational climate, supervisorsubordinate relationships (Kwon, Farndale, \& Park, 2016).

The Employee Engagement Dimensional Local Context and Global Context. Employee engagement in Indonesia context more concern in how the employee get equal facilities at workplace. In other words, employee external factors give significantly impact to employee than employee internal factors. Job importance, colleagues support, supervisor attention, growth (Widjaja \& Devie, 2014), organization communication, organization climate (Wijaya, 2015), job challenges, growth opportunities chance, work ability, work rightfully proud (Putri, Baga, \& Sunarti, 2015 ), incentive, allowance, workplace environment, promotion opportunities, job challenge, harmonizing, precisely, openness, goal oriented, coordinating, accuracy (Sri Widodo \& Sami'an, 2013), leadership, workplace condition, achievement, work quantity, work quality, time accuracy, presence, teamwork (Ramadhan \& Sembiring, 2014) as external factors, plays important role to improve engagement in Indonesia.

Table 1 - The description of employee engagement local context and global context through many literatures

\begin{tabular}{|c|c|c|}
\hline No & $\begin{array}{l}\text { Employee engagement dimension local context } \\
\text { (Indonesian Context) }\end{array}$ & Employee engagement dimension in Global context \\
\hline 1 & $\begin{array}{l}\text { Company facilities dimension } \\
\text { expectation and company facilities, What do I } \\
\text { Give-dimension is contained workplace, work } \\
\text { acknowledgment, supervisor attention, } \\
\text { colleagues support, Do I belong-dimension is } \\
\text { contained involvement, job importance, } \\
\text { colleagues commitment, trusted colleagues, } \\
\text { How can we grow-dimension is contained } \\
\text { progress report, growth (personal achievement) } \\
\text { (Widjaja \& Devie, 2014) }\end{array}$ & $\begin{array}{l}\text { Individual dimension } \\
\text { customer connection, participation, involvement or } \\
\text { absorption (Cambra-Fierro, Melero-Polo, \& Vazquez- } \\
\text { Carrasco, 2014) } \\
\text { Compensation Dimension } \\
\text { Salary (Cambra-Fierro, Melero-Polo, \& Vazquez- } \\
\text { Carrasco, 2014) } \\
\text { Organization Dimension } \\
\text { training received, work conditions, the socio-cultural } \\
\text { profile of the employee, feelings towards the company or } \\
\text { compatibility with company values (Cambra-Fierro, } \\
\text { Melero-Polo, \& Vazquez-Carrasco, 2014) }\end{array}$ \\
\hline
\end{tabular}




\begin{tabular}{|c|c|c|}
\hline 2 & $\begin{array}{l}\text { Communication and Organization system } \\
\text { Dimension } \\
\text { Good internal communication inside the } \\
\text { organization and organization culture. The } \\
\text { internal communication involved (1) event, (2) } \\
\text { structure (formal and informal), (3) flow } \\
\text { (downward and upward), (4) Content } \\
\text { (organizational and personalized), (5) Climate } \\
\text { (openness, participation, equality and } \\
\text { supportiveness). The organizational culture } \\
\text { involves (1) touching human feel or emotion, (2) } \\
\text { 8M culture, (3) "Good people" motto, (4) Value } \\
\text { System, (5) reward and punishment (Wijaya, } \\
2015 \text { ) }\end{array}$ & $\begin{array}{l}\text { Organization Dimension } \\
\text { employee welfare, empowerment, employee growth and } \\
\text { interpersonal relationships, Connect, Career, Clarity, } \\
\text { Convey, Congratulate Contribute, Control, Collaborate, } \\
\text { Credibility \& Confidence, contributions, connections, } \\
\text { growth and advancement, employee involvement and } \\
\text { commitment, leadership, relationships at work, total } \\
\text { reward, recognition, work life balance and work itself, } \\
\text { Individual Dimension } \\
\text { say, stay, strive, jobs satisfaction, feeling valued and } \\
\text { involvement, } \\
\text { Leadership dimension } \\
\text { equal opportunity, health and safety, length of services, } \\
\text { communication and co-operation, three predictors of } \\
\text { employee engagement (rational-employee understand } \\
\text { the role, emotional-employee passion at workplace, } \\
\text { motivational-employee discretionary effort to perform } \\
\text { their role), career opportunities, brand alignment, } \\
\text { recognition, people/hr practices, organization reputation, } \\
\text { managing performance, pay, valuing people (Bedarkar \& } \\
\text { Pandita, 2014) }\end{array}$ \\
\hline 3 & $\begin{array}{l}\text { Organization system and culture dimension } \\
\text { (a) achievement (job challenges, growth } \\
\text { opportunities chance, work ability, job } \\
\text { importance, appreciation, and work rightfully } \\
\text { proud), (b) Camaraderie ( colleagues relation, } \\
\text { team work, team work with other division, and } \\
\text { work team entire the organization) (c) } \\
\text { Leadership (instruction, decision making, } \\
\text { encouragement, communication, guidance, } \\
\text { discipline, supervisory, warning) (Putri, Baga, \& } \\
\text { Sunarti, 2015) }\end{array}$ & $\begin{array}{l}\text { (1) work environment (2) HRM Practices (3) employee } \\
\text { supervisor relationship (4) job satisfaction (5) } \\
\text { organizational culture (Kaliannan \& Narh Adjovu, 2015) }\end{array}$ \\
\hline 4 & $\begin{array}{l}\text { Internal employee feeling dimension } \\
\text { feeling energize (vigor), dedicated into their } \\
\text { work (dedication), commitment and find difficult } \\
\text { to detach from their work (Harry N, 2014) }\end{array}$ &  \\
\hline 5 & $\begin{array}{l}\text { Demographics dimension and organization } \\
\text { returns dimension } \\
\text { compensation, employee engagement with } \\
\text { recognition, employeer development } \\
\text { opportunities with employee engagement, and } \\
\text { age and work experiences with total returns } \\
\text { (Wuladari \& Gustomo, 2011) }\end{array}$ & $\begin{array}{l}\text { Communication Dimension } \\
\text { sharing of information and deliberately sense of } \\
\text { communication entire the organization (Karanges, } \\
\text { Johnston, Beatson, \& Lings, 2015) } \\
\text { Individual Dimension } \\
\text { "positive, fulfilling, work-related state of mind, the } \\
\text { benefits of employee engagement include increased } \\
\text { productivity, decreased attrition, improvement of an } \\
\text { organization's image and reputation, and increased } \\
\text { financial returns" (Schaufeli et al (2002) in (Karanges, } \\
\text { Johnston, Beatson, \& Lings, 2015)). }\end{array}$ \\
\hline 6 & $\begin{array}{l}\text { Compensation Dimension } \\
\text { incentive, allowance, workplace environment, } \\
\text { promotion opportunities, and job challenge } \\
\text { harmonizing, precisely, openness (Dewi, 2012) }\end{array}$ & $\begin{array}{l}\text { Individual Dimension } \\
\text { (1) feeling safe (incident prevention, trust and fairness } \\
\text { along with other, realities) (2) boredom (lack of work } \\
\text { perform, challenges, withdrawal behavior), (3) employee } \\
\text { engagement (enthusiastic, involved, absorbed) } \\
\text { (Whiteoak \& Mohamed, 2015) }\end{array}$ \\
\hline
\end{tabular}




\begin{tabular}{|c|c|c|}
\hline 7 & $\begin{array}{l}\text { Organization Dimension } \\
\text { goal oriented, coordinating each other, } \\
\text { accuracy, problem solving (Sri Widodo \& } \\
\text { Sami'an, 2013) }\end{array}$ & $\begin{array}{l}\text { Individual Dimension } \\
\text { job satisfaction, affective organizational commitment, job } \\
\text { involvement, vigor, dedication, absorption, focal } \\
\text { performance, contextual performance, contribute to one's } \\
\text { work role, social support (performance feedback, } \\
\text { autonomy, learning opportunities, task variety), employee } \\
\text { basic needs (autonomy, relatedness, competence), work } \\
\text { demands (time, task difficulty), high job performance, } \\
\text { high role performance, organizational citizenship } \\
\text { behaviors, personal initiative, higher likelihood of } \\
\text { promotion, absenteeism, tardiness, lower turnover and } \\
\text { retention, less complaints, workaholism, innovative } \\
\text { (Mackay, Allen, \& Landis, 2016) }\end{array}$ \\
\hline 8 & $\begin{array}{l}\text { Organization Dimension } \\
\text { (1) equity (how the organization maintain their } \\
\text { (a) workplace condition (b) compensation (c) } \\
\text { equally feel), (2) achievement, (3) Camaraderie, } \\
\text { (4) Leadership (how the organization provide } \\
\text { facilities about a) balancing between } \\
\text { organization vision and mission and operational } \\
\text { level b) Promoting and teamwork support c) } \\
\text { Support the employee to develop d) Support } \\
\text { and recognition appropriately) (Ramadhan \& } \\
\text { Sembiring, 2014) } \\
\text { Individual-Job Dimension } \\
\text { work quantity, work quality, time accuracy, } \\
\text { presence, ability to do teamwork (Ramadhan \& } \\
\text { Sembiring, 2014) }\end{array}$ & $\begin{array}{l}\frac{\text { Individual Dimension }}{\text { vigor, absorption, and dedication in one's work and its }} \\
\text { important to organizational performance (E, McNamara, } \\
\text { Pitt-Catsouphes, \& Valcour, 2015) } \\
\text { Individual dan family Dimension } \\
\text { positive and negative feeling outcome toward the job, } \\
\text { work-life balance defined as concern on relationships, } \\
\text { connections between work and family which is described } \\
\text { as work, family, personal roles, frone and his colleagues, } \\
\text { (E, McNamara, Pitt-Catsouphes, \& Valcour, 2015) }\end{array}$ \\
\hline 9 & - & $\begin{array}{l}\text { Organizational System } \\
\text { safety climate (safety training, open communication, } \\
\text { frequent safety inspections, good housekeeping, } \\
\text { environmental control, a stable workforce, promotion) } \\
\text { (Huang, et al., 2015). }\end{array}$ \\
\hline 10 & - & $\begin{array}{l}\text { Individual Dimension } \\
\text { (1) the degree of job importance (2) entitlement norms } \\
\text { that should developed (3) economic orientation through } \\
\text { high perform at their job (4) colleagues relationship (5) } \\
\text { fun expression, interest expression at workplace (6) high } \\
\text { contribution (Jung \& Yoon, 2015) } \\
\text { vigor, dedication, and absorption" (Jung \& Yoon, 2015) }\end{array}$ \\
\hline 11 & - & $\begin{array}{l}\text { Individual Dimension } \\
\text { work vigorously, feeling dedicated and mentally } \\
\text { absorbed in their work, also, have mindsets about } \\
\text { organizational culture, managerial actions, self- } \\
\text { development, enthusiasm for development, construal of } \\
\text { effort, focus of attention, perspective on setbacks, } \\
\text { interpersonal interactions (Keating \& Heslin, 2015) }\end{array}$ \\
\hline 12 & - & $\begin{array}{l}\text { Individual Dimension } \\
\text { (1) the degree of physical, cognitive, and emotional } \\
\text { involvement in workplace, good interactions, (2) energy, } \\
\text { involvement, efficacy (similar with vigor, dedication and } \\
\text { absorption) and willingness to invest effort and } \\
\text { endurance of difficulties (Lee \& Ok, 2015) } \\
\text { Individual Dimension-CSE (core self-evaluation) } \\
\text { "subconsciously appraise themselves, other people, and } \\
\text { the world or reality", "those perceptions shared among } \\
\text { members of organization about organizational } \\
\text { environment including policies, procedures, and } \\
\text { practices" (Lee \& Ok, 2015) } \\
\text { Individual Dimension - PSC (Psychological Climate) } \\
\text { (1) role-stress and lack of harmony (2) job challenge and } \\
\text { autonomy (3) leadership facilitation and support (4) work } \\
\text { group cooperation, friendliness, and warmth (Lee \& Ok, } \\
\text { 2015). }\end{array}$ \\
\hline
\end{tabular}


Different with Indonesian context, Global context of employee engagement more concern on how the individual manners, organizational system, and leadership dimension plays simultaneously role to boost employee engagement such as, participation, involvement, absorption (Cambra-Fierro, Melero-Polo, \& Vazquez-Carrasco, 2014), say, strive, job satisfaction, feeling valued, communication, careerist orientation, team identification, supervisor attitudes, knowledge, employee perception, OCB, interactional justice (Sivadahasan Nair \& Salleh, 2015), sharing information, sense of communication (Karanges, Johnston, Beatson, \& Lings, 2015), feeling safe (incident prevention, trust, fairness), boredom, enthusiastic, involved, absorbed (Whiteoak \& Mohamed, 2015) etc.

The comparison and similarity employee engagement local context or Indonesia context with global context in simple will described as table 1.

\section{CONCLUSION}

Even, first perception shown that Employee engagement in Indonesia context and global has similarity. But, in deeply, Indonesia context more concern on employee external dimension in other words organization dimension is play important role to boost emloyee engagement. Moreover, Global context gave balance view between organizational, job, leadership, and individual dimension in practice areas. The unique results is eventhough from this study mentioned that organizational perspective play important manner but in some part found that individual dimension mostly concern in Indonesia context is touching employee emotion feeling, harmonizing between employee with employee and employee with employer is important to booster engagement in the company. Also, balancing between vision and mission and the operational level in the organization is the important to build engagement in Indonesia context. Even, actually, Global context already described all of dimension comprehensively, Indonesia context has more specific in some parts that unique to discuss in the future.

Limitation. This study conducted in literature review, the consequences is lack of evidence in practice area. So, it should be proven in the field how the conclusion is created. Thus, more research is added in the future research is necessarily in purpose to get more comprehensively view in employee engagement in Indonesia context.

\section{REFERENCES}

1. Asian Development Outlook. (2016, January 1). Asian Development Bank: Home: Indonesia: Indonesia Economy. Retrieved from Asian Development Bank Web Site: https://www.adb.org/countries/indonesia/economy

2. Bedarkar, M., \& Pandita, D. (2014). A study on the drivers of employee engagement impacting employee performance. Elsevier: Procedia - Social and Behavioral Sciences, 106-115.

3. Cambra-Fierro, J., Melero-Polo, I., \& Vazquez-Carrasco, R. (2014). The role of frontline employees in customer engagement. Elsevier: Revista Espanola de Investigacion de Marketing ESIC, 67-77.

4. Dewi, D. I. (2012). Pengaruh Kompensasi dan Penliaian Kinerja Terhadap Employee Engagement di PT Asuransi Jasa Indonesia (Perseo) Kantor Pusat. Jakarta: Fakultas IImu Sosial dan IImu Politik, Departemen IImu Administrasi, Universitas Indonesia.

5. E, C. K., McNamara, T. K., Pitt-Catsouphes, M., \& Valcour, M. (2015). Lingking shifts in the national economy with changes in job satisfaction, employee engagement and worklife balance. Elsevier: Journal of Behavioral and Experimental Economics, 40-54.

6. Farndale, E., Kelliher, C., \& Hope-Hailey, V. (2014). Work and organisation engagement: aligning research and practice. Emerald: Journal of Organizational Effectiveness: People and Performance, 157-176.

7. Harry N, A. M. (2014). Pengaruh Kompensasi, Status/Pengakuan dan Kesempatan Berkembang Terhadap Tingkat Employee Engagement pada Karyawan Universitas Sanata Dharma. Yogyakarta: Magister Manajemen: Universitas Atma Jaya. 
8. Huang, Y.-H., Lee, J., McFadden, A. C., Murphy, L. A., Robertson, M. M., Cheung, J. H., \& Zohar, D. (2015). Beyond safety outcomes: An investigation of the impact of safety climate on job satisfaction, employee engagement and turnover using social exchange theory as the theoritical framework. Elsevier: Applied Ergonomics, 0003-6870.

9. Indonesia Investments. (2016, September 22). Home: Budaya: Demografi: Penduduk Indonesia. Retrieved from Indonesia Investments: http://www.indonesiainvestments.com/id/budaya/penduduk/item67

10. Jung, H. S., \& Yoon, H. H. (2015). What does work meaning to hospitality employees ? the effects of meaningful work on employees' organizational commitment: The mediating role of job engagement. Elsevier: International Journal of Hospitality Management, 02784319.

11. Kaliannan, M., \& Narh Adjovu, S. (2015). Effective employee engagement and organizational success: A case study. Elsevier: Procedia - Social and Behavioral Sciences, 161-168.

12. Karanges, E., Johnston, K., Beatson, A., \& Lings, I. (2015). The influence of internal communication on employee engagement: A pilot study. Elsevier: Public Relations Review, 0363-8111.

13. Keating, L. A., \& Heslin, P. A. (2015). The potential role of mindsets in unleashing employee engagement. Elsevier: Human Resource Management review, 1-13.

14. Kwon, B., Farndale, E., \& Park, J. G. (2016). Employee voice and work engagement: Macro, meso, and micro-leve drivers of convergence. Elsevier: Human Resource Review, 1053-4822.

15. Lee, J. (2015). Drivers of work engagement: An examination of core self-evaluations and psychological climate among hotel employees. Elsevier: International Journal of Hospitality Management, 0278-4319.

16. Mackay, M. M., Allen, J. A., \& Landis, R. S. (2016). Investigating the incremental validity of employee engagement in the prediction of employee affectiveness: A meta-analytic path analysis. Elsevier: Human Resource Management Review, 1053-4822.

17. Millar, G. (2012). Employee Engagement - a new paradigm. Human Resource Management International Digest, 3-5.

18. Putri, M. S., Baga, L. M., \& Sunarti, E. (2015). Employee Engagement, Lingkungan Sosial dan Kinerja Karyawan di PT Bank Rakyat Indonesia Tbk, Kantor Cabang Bogor Dewi Sartika. Manajemen IKM, 123-130.

19. Ramadhan, N., \& Sembiring, J. (2014). Pengaruh Employee Engagement Terhadap Kinerja Karyawan di Human Capital Center PT. Telekomunikasi Indonesia, Tbk. Jurnal Manajemen Indonesia, 47-58.

20. Schaufeli, W. B., Salanova, M., Gonzalez-Roma, V., \& Bakker, A. B. (2002). The Measurement of Engagement and Burnout: A Two Sample Confirmatory Factor Analytic Approach. Journal of Happiness Studies, 71-92.

21. Sivadahasan Nair, M., \& Salleh, R. (2015). Lingkiing Perfomance Appraisal Justice, Trust, and Employee Engagement: A Conceptual Framework. Elsevier: Procedia - Social and Behavioral Sciences, 1155-1162.

22. Sri Widodo, F. A., \& Sami'an. (2013). Hubungan Employee Engagement dengan Perilaku Produktif Karyawan. Jurnal Psikologi Industri dan Organisasi, 2(1).

23. Taneja, S., Sewell, S. S., \& Odom, R. Y. (2015). A Culture of employee engagement: A strategic perspective for global managers. Emerald: Journal of Business Strategy, 46-56.

24. Tiwari, B., \& Lenka, U. (2016). Building pyschological safety for employee engagement in post-recession. Emerald: Development and Learning in Organizations, 19-22.

25. Tradingeconomics. (2015, August 05). Indonesia GDP Annyal Growth Rate: Data: Chart: Calender: 2000-2016. Retrieved from Trading Economics Web Ste: http://www.tradingeconomics.com/indonesia/gdp-growth-annual

26. Ugwu, F. O., Onyishi, I. E., \& Rodriguez-Sanchez, A. M. (2014 ). Lingking organizational trust with employee engagement: the role of psychological empowerment. Emerald Personnel Review, 377-400. 
27. Vance, R. J. (2006). Employee Engagement and Commitment. United States of America: SHRM Foundation.

28. Whiteoak, J. W., \& Mohamed, S. (2015). Employee Engagement, boredom and frontline construction workers feeling safe in their workplace. Elsevier: Accident Analysis and Prevention, 0001-4575.

29. Widjaja, J., \& Devie. (2014). Pengaruh Job Satisfaction Terhadap Financial Performance Melalui Employee Engagement and Competitive Advantage Sebagai Intervening Variable Pada Perusahaan Retail Publik di Surabaya. Business Accounting Review, 99100.

30. Wijaya, F. (2015). Strategi Komunikasi Internal PT X Dalam Membina Employee Engagement. Jurnal E-Komunikasi, 3 (1).

31. Worldometers. (2015, January 1). W: Population: World: Asia: South-Eastern Asia: Indonesia. Retrieved from Indonesia Population (Live): http://www.worldometers.info/world-population/indonesia-population/

32. Wuladari, P., \& Gustomo, A. (2011). Analisis Pengaruh Total Returns terhadap Tingkat Engagement Dosen Institut Teknologi Bandung. Bandung: Magister Sains Manajemen: Sekolah Bisnis dan Manajemen Institut Teknologi Bandung. 